\title{
MEDICINE
}

\section{STUDY OF THE LIPID COMPOSITION OF SOME PLANTS GROWING IN GEORGIA}

\author{
B. Kikalishvili, A.D.Ph. \\ Ts. Sulakvelidze, A.D.Ph. \\ M. Malania, M.Ch. \\ D. Turabelidze, A.D.Ph.
}

\section{Kutateladze Institute of Pharmacochemistry of Tbilisi State Medical University, Tbilisi, Georgia}

DOI: https://doi.org/10.31435/rsglobal_wos/31032019/6390

\begin{tabular}{|c|c|}
\hline ARTICLE INFO & ABSTRACT \\
\hline $\begin{array}{l}\text { Received: } 15 \text { January } 2019 \\
\text { Accepted: } 11 \text { March } 2019 \\
\text { Published: } 31 \text { March } 2019\end{array}$ & $\begin{array}{l}\text { Sums of neutral and polar lipids were extracted from the fruits of Vitis } \\
\text { vinifera and pericarpium of Physalis alkekengi L.; their main classes and } \\
\text { physical-chemical constants of some neutral lipids were determined. The }\end{array}$ \\
\hline $\begin{array}{l}\text { KEYWORDS } \\
\text { neutral, } \\
\text { polar lipids, } \\
\text { phospholipids, } \\
\text { carotenoids, } \\
\text { fatty acids. }\end{array}$ & $\begin{array}{l}\text { using High Performance Liquid Chromatography. The phospholipids- } \\
\text { lysophosphatidylcholine, phosphatidylinosite, phosphatidylcholine, } \\
\text { phosphatidylethanolamine and N-acyl phosphatidylethanolamine were } \\
\text { identified in them. The content of carotenoids is up } 2,5 \mathrm{mg} \% \text { and } \\
65,5 \mathrm{mg} \% \text { in Vitis vinifera and Physalis alkekengi L. respectively. } \\
\text { Amino acids were detected in studied species. The oils from both plants } \\
\text { are characterized with anti-inflammatory, hepatoprotective, choleretic } \\
\text { and immunotropic activities, they can be used in medicine for curative } \\
\text { and preventive purposes. }\end{array}$ \\
\hline
\end{tabular}

Citation: B. Kikalishvili, Ts. Sulakvelidze, M. Malania, D. Turabelidze. (2019) Study of the Lipid Composition of Some Plants Growing in Georgia. International Academy Journal Web of Scholar. 3(33). doi: 10.31435/rsglobal_wos/31032019/6390

Copyright: (C) 2019 B. Kikalishvili, Ts. Sulakvelidze, M. Malania, D. Turabelidze. This is an openaccess article distributed under the terms of the Creative Commons Attribution License (CC BY). The use, distribution or reproduction in other forums is permitted, provided the original author(s) or licensor are credited and that the original publication in this journal is cited, in accordance with accepted academic practice. No use, distribution or reproduction is permitted which does not comply with these terms.

Introduction. Among of the biologically active natural compounds, vegetation lipids, which are a part of all living cells and biological membranes, play an important role. Lipids participate in the vital processes of the organism what evidences their important physiological role. As the literary data suggest, their action is various: immunotropic, hepatoprotective, choleretic, antiallergenic, anti-inflammatory and cytotoxic. They reduce the risk of atherosclerosis and cardio-vascular diseases [1,2].

Grape - Vitis vinifera are widely spread in Western and Eastern Europe and grows in almost all regions of Georgia [3, 4]. As the literary data suggest, the fruits of grape contain vitamins, anthocyanins, carbohydrates and organic acids. Grape seeds contain oil and pectin. They are used to treat avitaminosis, rachitis, anemia and hepatic diseases and as tonic $[5,6]$.

Bladder cherry - Physalis alkekengi L. commonly grows all over the territory of Georgia [3]. Based on the literary data, it contains organic acids, alkaloids, carotins, pectins, mineral substances, phytoncides, fatty and essential oils. Its pericarpium has anti-inflammatory, choleretic, diuretic, antiseptic and analgetic actions. It is used to treat rheumatism, respiratory tract diseases, inflammatory processes of the urinary system. The oil extracted from its fruits can reduce level of cholesterol in blood and liver, restores immune and hormonal systems and improves liver functions. 
Goal of the study. The goal of the study is to explore some plants growing in Georgia for the content of lipids and accompaning biologically active substances. The objects of the study are plants growing in Georgia: Vitis vinifera (Vitaceae) -fruits and Physalis alkekengi L. (Solanaceae) pericarpium.

Results of the study. The sum of neutral lipids (yield 12\%) was obtained from air-dried fruit of grapes by 4-fold cold extraction with hexane. The main classes were identified and some physical-chemical constants were determined: acid number $2,2 \mathrm{mgKOH} / \mathrm{g}$; saponification number $-180-210 \mathrm{mgKOH} / \mathrm{g}$. and iodine number - 150-180\%. Identification of free acids was carried out by High Performance Liquid Chromatography (HPLC) on the apparatus PTG-1 with the refractive detector R-401 and reverce phase column bondapak C. Eluent 1-methanol-water (1:2); eluent 2-tetrahydrofuran-acetonitrile-water (5:7:9) + $0,1 \%$ acetic acid solution. The results were processed using the OASIS-740 software. The following fatty acids- hexadecane, octadecane, octadecene, octadecadiene, octadecatriene and eicosane were identified $[7,8]$. The content of carotenoids in the sum of neutral lipids is $2,5 \mathrm{mg} \%$.

The sum of polar lipids (yield 2,3\%) was obtained from the fruits of grape after the obtaining of neutral lipids by 4 fold extraction with chloroform-methanol mixture 2:1 at the room temperature. Qualitative analysis of polar lipids was carried by bidirectional chromatography using the following solvent systems: 1) chloroform:methanol:ammonia (60:30:5); 2) chloroform:methanol:glacial acetic acid:water $(170: 25: 25: 6)$. The plates were processed with iodine vapor and Vaskovski's reagent. Qualitatively, the following phospholipids- lysophosphatidylcholine, phosphatidylinosite, phosphatidylcholine, phosphatidylethanolamine and $\mathrm{N}$-acyl phosphatidylethanolamine were identified in the studied object. Also the amino acids: lysine, asparagines, alanine, serine, phenylalanine and valine were determined.

The sum of neutral lipids (yield 10\%) was obtained of 4-fold extraction with hexane from airdried pericarpium of bladder cherry. Its main classes [9] and some of its physical-chemical properties such as: acid number $0,76 \mathrm{mgKOH} / \mathrm{g}$; iodine number $-106 \%$, refraction index $-1,467$ and specific weight $-0,926$ were also determined. The content of carotenoids in the sum of neutral lipids of bladder cherry's pericarpium is $65,5 \%$.

By using HPLC eight fatty acids were identified: dodecane, tetradecane, hexadecane, octadecane, octadecene, octadecadiene, octadecatriene, eicosane.

After isolation of neutral lipids from the raw material the sum of polar lipids (yield 1,2\%) was obtained by extraction with chloroform-methanol mixture 2:1. Qualitatively, the following phospholipids were identified: phosphatidylinosite, phosphatidylcholine, phosphatidylethanolamine and $\mathrm{N}$-acyl phosphatidylethanolamine. The quantitative content of total phospholipids was determined by using spectrophotometric method, and it is $0,55 \%$. The following amino acids- lysine, phenylalanine, valine, leicine, arginine, serine and glycine were identified in the bladder cherry.

Conclusions. Thus, by using HPLC dominant saturated fatty acid in the sum of neutral lipids extracted from the fruit of Vitis vinifera is hexadecanoic acid and 9,12-octadecadiene dominates as unsaturated fatty acid.

Dominant saturated fatty acid in the sum of neutral lipids extracted from the pericarpium of Physalis alkekengi L. is octadecane and octadecene dominates as unsaturated fatty acid.

Based on the literary data [5,6], the lipids obtained from the studied objects can be recommended for using in medical practice.

\section{REFERENCES}

1. Адекенов C.M. Новые оригинальные фитопрепараты, перспективы применения в медицине и организация их производства. Фармация Казахстана.2009; т.1.Раздел 3.201-205.

2. Шипов А.Н., Макаров В.Г. Рыженков В.Е. Растительные масла и масляные экстракты. М.Русский врач. 2004.119.

3. Gagnidze R. Vascular plants of Georgia, a nomenclatural checking. Tbilisi; 2005.

4. Flora Georgiae. v. VIII. Tbilisi, «Metsniereba», 1983.276.

5. Kikalishvili B., Zurabashvili D., Turabelidze D., Zurabashvili Z., Giorgobiani I. Fatty acids of grape seed oil and its biological activity as 1,0\% and 2,5\% food-additive. Georgian Medical News.N6(207) 2012.

6. Kikalishvili B., Zurabashvili D., Nikolaishvili M., Zurabashvili Z., Giorgobiani I. The fatty acid composition of Rkatsiteli grape seed oil and its effect as a food-additive. Georgian Medical News. N2(191) 2011.

7. Зурабашвили 3.А. Сунозова Е.В. Хроматографический анализ жиров и масел.М.2010.

8. Dhellot G., Matoube E. Extraction chemical composition and nutritional characterization of vegetable oils. African Biotechnol. 2006;5 (11); 1095-2101.

9. Spongord R.Y. Sun M. Enchancement of an analytical method for the determination oils in viecine adsorbe formulations. J.Parrm./ biomed.Anal. 2008; 52; 554-564. 